\title{
Perancangan Komunikasi Visual Kampanye Pengurangan Konsumtivisme
}

\author{
Elfa Swaratama \\ Program Pascasarjana Institut Seni Indonesia Yogyakarta \\ elfaswaratama@gmail.com
}

\begin{abstract}
Abstrak
Perilaku konsumtif dapat mengakibatkan dampak-dampak negatif seperti membuat seseorang untuk memiliki pola hidup boros dan dapat membuat orang menjadi tidak lagi membedakan antara kebutuhan akan tetapi mengutamakan keinginan. Perancangan komunikasi visual, kampanye pengurangan konsumtivisme ini bertujuan untuk mengurangi sifat konsumtif khususnya generasi muda. Metode pengumpulan data yang digunakan dalam perancangan ini adalah kualitatif deskriptif, serta perancangan ini melalui tiga tahap, yaitu pembuatan konsep kampanye, konsep media, dan pembuatan konsep kreatif berdasarkan studi literatur, observasi, dan wawancara terhadap target audiensi. Berdasarkan penelitian berupa observasi dan wawancara terhadap target audiensi didapati bahwa media-media yang akan digunakan sebagai media kampanye berdasarkan intensitas pemakaiannya adalah sosial media Facebook dan Instagram. Sedangkan isi pesan yang akan disampaikan adalah "Belilah Barang sesuai dengan Fungsinya", dengan cara penyajian pesan yaitu dengan menggunakan humor satir. Kampanye ini dirancang dalam bentuk lima buah poster yang akan disebarkan di media sosial seperti yang telah disebutkan di atas, dengan karakter visual dan verbal yang kontroversial. Penggunaan karakter tersebut diharapkan dapat membantu target audiensi untuk turut menyebarkan pesan tersebut sehingga kampanye ini akan menjadi viral.
\end{abstract}

Kata kunci: desain komunikasi visual, konsumtif, viral, kampanye

\begin{abstract}
Consumer behavior can lead to negative effects such as making a person to have an extravagant lifestyle and can make people no longer distinguish between needs and desire. Visual communication design consumerism reduction campaign aims to reduce the consumptive nature of the young generation. Data collection methods used in this design is qualitative descriptive, and this design through three stages, namely the concept of the campaign, the concept of media, and the making of creative concepts based on the study of literature, observation, and interviews with the target audience. Based on research in the form of observations and interviews with the target audience, found that the media will be used as a media campaign based on the intensity of their use of social media is Facebook and Instagram. While the contents of the message to be conveyed is "buy goods in accordance with its function", by way of presenting a message that is using satirical humor. The campaign is designed in the form offive posters that will be distributed in social media such as those mentioned above, with the controversial visual and verbal content that is expected to help the target audience to also spread the message so that this campaign will become viral.
\end{abstract}

Keywords: visual communication design, consumerism, viral, campaign 


\section{Pendahuluan}

Manusia dalam sebuah kehidupan sebenarnya hanya membutuhkan tiga hal pokok yaitu pakaian, makanan, dan tempat tinggal untuk bisa bertahan hidup dan membangun kebudayaan dalam sebuah kelompok masyarakat. Dengan kehidupan yang modern serta pertambahan laju ekonomi dalam sebuah negara, masyarakat dihadapkan dengan kebutuhan sekunder dan kebutuhan tersier yang mempunyai nilai tukar dalam kehidupan masyarakat. Jika nilai primer dijadikan acuan untuk menjalani kehidupan, nilai sekunder sebagai alat bantu dalam menjalankan kehidupan, maka nilai tersier adalah sebuah nilai yang mendampingi kehidupan sebagai hiburan. Dewasa ini kebutuhan sekunder dan tersier terlihat sebagai sebuah nilai tukar, di mana nilai tukar ini bukan berupa barang namun berupa nilai tukar sosial. Dengan melakukan nilai tukar secara sosial tersebut, sebuah individu dapat mendapatkan tempat di sebuah masyarakat dengan sebuah strata atau kedudukan dalam masyarakat. Hal tersebut yang memunculkan stratifikasi kedudukan seseorang melalui barang yang mereka punyai, mulai dari rumah mewah, mobil, peralatan elektronik, sampai ke dalam pakaian yang mengarah kepada sebuah mode atau fashion dalam trend terkini. Sehingga keadaan tersebut menjadi sebuah gaya hidup yang dikenal sebagai sebuah sifat konsumtif.

Perilaku konsumtif adalah suatu perilaku yang tidak lagi didasarkan pada pertimbangan yang rasional, melainkan karena adanya keinginan yang sudah mencapai taraf yang tidak rasional lagi (Lina dkk, 2008: 177). Dewasa ini salah satu gaya hidup konsumen yang cenderung terjadi di dalam masyarakat adalah gaya hidup yang menganggap materi sebagai sesuatu yang dapat mendatangkan kepuasan tersendiri, gaya hidup seperti ini dapat menimbulkan adanya gejala konsumtivisme, sedangkan konsumtivisme dapat didefinisikan sebagai pola hidup individu atau masyarakat yang mempunyai keinginan untuk membeli atau menggunakan barang dan jasa yang kurang atau tidak dibutuhkan (Lestari, 2006). Sesuai dengan penjelasan di atas, bahwa secara harafiah hal tersebut merupakan sifat dasar manusia.

Perilaku ini sebenarnya dipengaruhi oleh beberapa faktor. Salah satunya adalah lingkup pengembangan industri dagang melalui internet yang sangat viral beberapa tahun ini. E-commerce yang dicanangkan oleh pemerintah mempunyai efek besar dalam sikap konsumtif tersebut. Belum lagi bidang internet lainnya seperti media sosial yang sekarang ini dijadikan semacam toko berjualan dan diunggah untuk kepentingan jual beli. Kemudahan dalam sistem jual beli yang hanya melihat dan dilanjutnya transfer pembayaran. Barang tersebut kebanyakan merupakan kebutuhan sekunder dan tersier, dari barang remeh-temeh sampai barang mewah seperti elektronik ataupun perhiasan.

Sejak tahun 1970-an hingga hari ini, Indonesia sudah dikenal sebagai negara paling konsumtif di dunia. Bahkan pada saat krisis ekonomi global melanda dunia di tahun 1998 dan 2008, Indonesia seolah tidak terpengaruh. Nilai belanja masyarakatnya meningkat cukup signifikan. Tidak saja di dalam negeri, namun juga di luar negeri. Di era 2000-an ini, kehidupan konsumtif masyarakat Indonesia semakin menjadi-jadi. Tidak heran jika Indonesia menjadi daya tarik dan sasaran bombardir barang dan produk dari berbagai dunia. Karena sudah dapat dipastikan produk apapun yang masuk Indonesia akan laris bak kacang goreng, mulai dari produk berkualitas paling rendah hingga paling 
tinggi sekali pun. (Chandra, http://www.kompasiana.com/mulyady1688/10-peringkatindonesia-didunia_54f934b0a3331 12c048b4a1a).

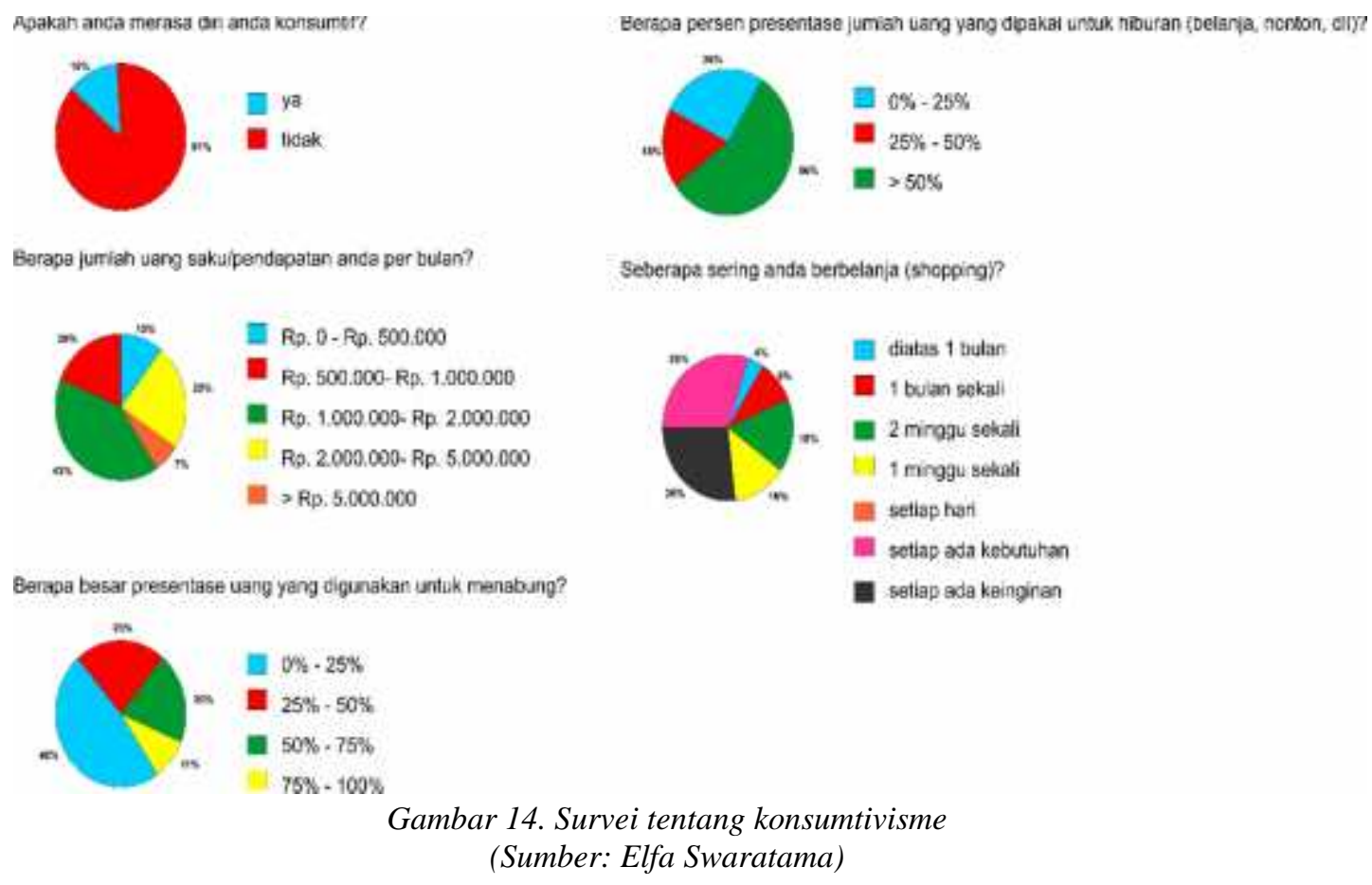

Menurut survei yang dilakukan pada 100 masyarakat Indonesia, 81\% responden menyatakan tidak konsumtif. Padahal, uang yang digunakan untuk menabung kurang dari 26\% dan 56\% responden membelanjakan lebih dari setengah uang saku per bulan untuk hiburan. Hal ini semakin diperparah dengan data dari Marknetter's (2013) yang menyatakan bahwa penggerak ekonomi pasar website jual beli online merupakan kaum muda, dengan rincian; remaja berumur 17-19 tahun menempati urutan pertama (34\%), dilanjutkan oleh netizen berumur 20-28 tahun (27\%) kemudian berumur 28-35 tahun (21\%) dan di atas 35 tahun (18\%). Dari sini kemudian disimpulkan bahwasanya pasar online sangat bergantung dari budaya konsumsi dari netizen yang berusia relatif muda. (Syamila, http://www.kompasiana.com/www.ahda syamil.com/saat-perilaku-konsumtifmenjadi-budaya-remaja_54f92016a33311f8478b4b84)

Menurut Rogers dan Storey (dalam Venus, 2004: 7), kampanye adalah serangkaian tindakan komunikasi yang terencana dengan tujuan untuk menciptakan efek tertentu pada sejumlah besar khalayak yang dilakukan secara berkelanjutan dalam kurun waktu tertentu. Kampanye sebagai salah satu bentuk upaya untuk mengurangi konsumtivisme yang terjadi pada netizen yang berusia relatif muda sangat diperlukan. Kampanye menggunakan berbagai macam bauran promosi serta mengedepankan nilai komunikasi dalam kampanye tersebut agar khalayak sasaran dapat dengan mudah memahami maksud dan tujuan yang ingin dicapai dalam kampanye tersebut (Dietrich dan Livingston, 2012: 2-4).

Perilaku konsumtif ini tentunya menguntungkan pihak produsen, namun jika perilaku ini dibiarkan, akan merusak karakter anak bangsa dimana kita hanya dijejali oleh 
sebuah produk namun tidak ada niatan untuk mandiri dalam menciptakan sebuah produk tersendiri. Hal tersebut juga menjadikan seseorang malas dalam memberikan inovasi sehingga generasi anak bangsa kita memenuhi kebutuhan dan hasrat dengan membeli apa yang ada di pasar.

\section{Metode Perancangan}

Perancangan ini secara garis besar dirancang dengan melalui empat tahap yakni:

1. Konsep Kampanye, yaitu berkaitan dengan apa yang ingin dicapai di dalam kampanye yaitu mengurangi konsumtivisme. Pada tahapan ini, strategi-strategi yang akan dipakai dalam upaya mencapai tujuan kampanye juga ditentukan.

2. Konsep Media, yaitu berhubungan dengan media-media terpilih yang akan digunakan dalam perancangan kampanye pengurangan konsumtivisme ini. Konsep media memegang peran penting karena berkaitan dengan pemilihan media-media yang efektif dan komunikatif dalam rangka keberhasilan kampanye. Media yang dipilih haruslah dilalui dengan selektif untuk menghindari membuang-buang biaya media. Dalam pembahasan ini konsep media dibagi menjadi dua bahasan yaitu tujuan media dan strategi media.

3. Konsep Kreatif, adalah suatu gagasan utama yang mendasari komunikasi visual yang akan dipakai dalam perancangan kampanye pengurangan konsumtivisme.

4. Visualisasi, yaitu tahapan terakhir dimana akan mengeksekusi visual berdasarkan dari konsep kreatif yang telah dibuat.

Adapun metode Pengumpulan Data menggunakan metode kualitatif deskriptif, yaitu suatu metode yang meliputi:

1. Mewawancarai remaja-remaja yang diduga melakukan tindakan konsumtif.

2. Mencari sumber-sumber literatur yang berasal dari buku dan internet.

3. Mengumpulkan dokumentasi berupa foto dan video yang berkaitan dengan masyarakat konsumtif.

4. Mengumpulkan berbagai foto dan video yang berkaitan dengan kampanye sosial dimana berkaitan dengan masyarakat konsumtif .

Analisis $5 \mathrm{~W} 1 \mathrm{H}$ yang digunakan berbasis pada obyek yang diangkat yaitu masyarakat atau remaja yang terkena konsumtivisme.

1. What: yang akan dirancang adalah kampanye sosial pengurangan konsumtivisme.

2. Where: perancangan ini akan dilakukan di media social.

3. When: kampanye ini diluncurkan bertepatan dengan Hari Konsumen Nasional, yaitu 20 April 2016.

4. Who: yang menjadi target audience dalam perancangan ini adalah Warga Negara Indonesia berumur 17 - 28 tahun, sedang atau telah menempuh pendidikan Strata 1 dengan tingkat ekonomi menengah, senang berbelanja online, serta senang memiliki barang bermerk terkenal.

5. Why: perancangan ini penting dilakukan mengingat tindakan konsumtivisme merupakan pemborosan.

6. How: perancangan ini dilakukan dengan cara mengingatkan target audience tentang dampak buruk konsumtivisme. 


\section{Budaya Konsumtif}

Perilaku konsumtif sebaiknya diwaspadai karena dapat mengakibatkan dampakdampak negatif seperti dapat menghabiskan seseorang untuk memiliki pola hidup boros, dapat membuat orang menjadi tidak lagi membedakan antara kebutuhan akan tetapi mengutamakan keinginan.

Sedangkan menurut Lina perilaku konsumtif adalah suatu peilaku yang tidak lagi didasarkan pada pertimbangan yang rasional, melainkan karena adanya keinginan yang sudah mencapai taraf yang tidak rasional lagi. Pengertian ini sejalan dengan pandangan Lina dan Rosyid yang menyatakan bahwa perilaku konsumtif melekat pada seseorang apabila orang tersebut membeli sesuatu diluar kebutuhan yang rasional, pembelian tidak lagi didasarkan pada faktor kebutuhan, tetapi sudah pada taraf keinginan yang berlebihan. (Lina dkk, 2008: 177)

Perilaku konsumtif memiliki beberapa dimensi yaitu:

1. Pemenuhan keinginan

Rasa puas pada manusia tidak berhenti pada satu titik saja melainkan cenderung meningkat. Oleh karena itu, dalam pengkonsumsian suatu barang mausia selalu ingin lebih untuk memenuhi rasa puasnya, meskipun sebenarnya tidak ada kebutuhan akan barang tersebut sehingga individu akan memilikli keinginan untuk membelanjakan uangnya dengan mengkonsumsi barang dan jasa secara terus-menerus untuk memenuhi rasa kepuasannya.

2. Barang di luar jangkauan Jika manusia menjadi konsumtif tindakan konsumsinya menjadi kompulsif dan tidak rasional. Individu tersebut selalu merasa " belum lengkap" dan mencari-cari kepuasan akhir dengan mendapatkan barang-barang baru. Dengan demikian individu tersebut tidak lagi mencari kebutuhan dirinya dan kegunaan barang itu bagi dirinya.

3. Barang tidak produktif Jika pengkonsumsian barang menjadi berlebihan maka kegunaan konsumsi menjadi tidak jelas, sehingga mengakibatkan barang atau produk tersebut menjadi tidak produktif.

4. Status

Perilaku individu bisa digolongkan sebagai konsumtif jika ia memiliki barang-barang yang lebih karena pertimbangan status. Manusia mendapatkan barang-barang untuk memilikinya. Konsumtif berkaitan dengan aspek selera. Selera merupakan media pengikat, masing-masing kelompok berkompetisi dalam penggunaan barang secara simbolik (Damsar, 2000: 42).

\section{Konsep Kampanye}

Dalam tujuan kampanye yaitu topik ini ramai dibicarakan oleh 300 target audience, maka dalam hal ini tujuan promosi adalah menentukan jumlah target audience yang akan disentuh dalam promosi. Tujuan promosi mengacu pada sumber dana dan kapasitas promosi yang akan dilakukan sehingga langkah-langkah yang dilakukan mempunyai arah dan tujuan. 
Menurut Suharta dalam Sanyoto (2006: 52), mengembangkan target market dapat dilakukan untuk mencapai target audience. Hal tersebut disebabkan adanya unsurunsur pemberi pengaruh (influencer), di samping unsur pemakai (user). Berdasarkan "influencing spheres" (lingkungan pemberi pengaruh) terdapat sedikitnya tiga orang yang bisa mempengaruhi terjadinya pembelian, sehingga jika diperhitungkan dengan dirinya maka jumlah minimal target audience sama dengan empat kali target market $(\mathrm{TA}=4 \mathrm{x}$ TM). Target audience yang berjumlah 1.200 orang didapat dari perhitungan $4 \mathrm{x}$ target market yang berjumlah 300 orang.

Bauran promosi yang akan dipakai dalam kampanye ini adalah:

1. Iklan

Setiap penyajian informasi yang bersifat berbayar dan non personal disebut iklan. Penyajiannya dapat berupa billboard, transit ad, maupun iklan digital yang dapat dicantumkan di website dan media sosial. Bahkan dengan teknologi yang semakin canggih sekarang ini, beriklan di aplikasi ponsel dapat menjadi pilihan yang cukup menguntungkan, karena sistem pembayarannya dapat pay per-click (membayar hanya jika ada user yang meng-click iklan tersebut).

2. Publikasi

Publikasi atau hubungan masyarakat antara lain dengan membuat berita komersial di dalam koran atau mengadakan jumpa pers untuk memberitahu kegiatan donasi kepada pers. Hal ini dilakukan untuk mendapatkan perhatian masyarakat tanpa harus membayar. Konten yang disajikan haruslah kreatif agar pers tertarik untuk memuat beritanya di koran. Pada era yang saling terkoneksi ini, publikasi juga dapat dibagi lewat media sosial. Hal ini dapat dilakukan dengan pemaksimalan konten agar user bersedia untuk menyebarkan informasi ini kepada rekan-rekan media sosialnya.

\section{Konsep Media}

Konsep media berhubungan dengan media-media terpilih yang akan digunakan dalam perancangan kampanye pengurangan konsumtivisme ini. Konsep media memegang peran penting karena berkaitan dengan pemilihan media-media yang efektif dan komunikatif dalam rangka keberhasilan kampanye. Media yang dipilih haruslah dilalui dengan selektif untuk menghindari membuang biaya media. Dalam pembahasan ini konsep media dibagi menjadi dua bahasan yaitu tujuan media dan strategi media. Tujuan media menjelaskan tentang apa yang ingin dicapai dalam media-media yang dipilih. Hal tersebut berkaitan dengan jangkauan, frekuensi, dan kesinambungan atau kontinuitas. Sedangkan strategi media berhubungan dengan langkah-langkah yang ditempuh dalam perancangan media tersebut.

1. Tujuan Media

Dalam tujuan media, harus dibentuk dari tiga aspek yaitu jangkauan, frekuensi, dan kesinambungan. Hal tersebut akan menjadi acuan media-media terpilih untuk memenuhi tujuan promosi.

a. Jangkauan (Reach)

Jangkauan perancangan kampanye pengurangan konsumtivisme ini sekurangkurangnya dapat menjangkau target audience sejumlah 1.200 orang yang berada di 
seluruh Indonesia. Tentunya dalam sebuah promosi perlu mengetahui jangkauan media yang akan dicari untuk mengukur efektivitas penggunaan media.

Media yang diukur berdasarkan tujuan promosi harus meraup sekurangkurangnya target audience berjumlah 1.200 orang, jumlah tersebut terhiting tiga bulan setelah kampanye dilaksanakan. Maka, dalam satu hari media yang terpilih sekurangkurangnya harus mempengaruhi lima orang. Masing-masing bauran promosi yang terpilih mendapat beban pengaruh dengan jumlah yang berbeda.

b. Frekuensi (Frequency)

Frekuensi berhubungan dengan waktu penayangan media dan sangat berpengaruh terhadap biaya media, namun dalam perancangan kampanye ini frekuensinya akan sangat beragam, karena menggunakan media digital.

c. Kesinambungan (Continuity)

Aspek kesinambungan bertujuan menyatakan jangka waktu kampanye yang direncanakan. Dalam tujuannya mempengaruhi target audience sebanyak 1.200 orang, maka perancangan ini membutuhkan sekurang-kurangnya 3 bulan sejak kampanye diluncurkan pertama kali.

2. Strategi Media

Strategi media merupakan suatu analisis dan solusi untuk mencapai tujuan media. Strategi media dibentuk oleh target audience dengan paduan media yang terdiri dari pilihan media dan jadwal media.

a. Khalayak sasaran

Penetapan target audience harus terukur sesuai dengan tujuan media yang telah ditetapkan. Khalayak sasaran meliputi segmentasi demografis, geografis, psikografis, dan perilaku (behaviour).

1) Demografis

Segmentasi demografis pada perancangan ini adalah remaja, dengan rentang umur 18 hingga 30 tahun, memiliki tingkat ekonomi menengah, dan berjenis kelamin lelaki atau perempuan.

2) Geografis

Berada di wilayah Negara Kesatuan Negara Indonesia atau mengerti bahasa Indonesia.

3) Psikografis

Psikografis sasaran dalam perancangan ini ialah mereka yang senang memiliki barang yang ber-merk terkenal.

4) Perilaku

Perilaku sasaran yang dipilih adalah mereka yang banyak menghabiskan waktu luangnya di internet terutama sosial media dan senang mengobrol dengan teman.

b. Paduan media

Memilih media berhubungan dengan pengoperasiannya yang sesuai dengan jadwal dan kebiasaan target audience. Hal tersebut berpengaruh terhadap efektivitas media dalam menjalankan perannya. Dalam perancangan kampanye pengurangan konsumtivisme, media yang digunakan adalah:

1) Facebook 
Akun Facebook akan digunakan sebagai sarana komunikasi kampanye ini dengan masyarakat. Penggunaan Facebook mengikuti kebiasaan target audience di mana menggunakan Facebook sebagai sarana komunikasi utama dibanding media sosial sejenis seperti Twitter dan Path (Andito, wawancara, 30 November 2015).

2) Instagram

Penggunaan Instagram mengikuti kebiasaan target audience dimana banyak mengakses menggunakan Instagram sebagai media sosialnya

\section{Konsep Kreatif}

Konsep kreatif atau bisa disebut big idea dalam perancangan kampanye ini adalah suatu gagasan utama yang mendasari komunikasi visual yang akan dipakai dalam perancangan kampanye pengurangan konsumtivisme. Dalam perancangan ini, tema yang dipakai adalah "Brand Attack". Konsep "Brand Attack" berawal dari penuturan saudara Alouisius Andito dimana dia mengaku tergila-gila membeli barang yang bermerk terkenal. Ia rela hampir seluruh gajinya digunakan untuk membeli barang-barang bermerk tersebut (wawancara, Andito, 30 November 2015). Brand Attack adalah menyerang brand-brand terkenal yang digandrungi oleh target audience. Diharapkan setelah melihat kampanye ini, Target Audience menjadi sadar bahwa mereka ternyata melakukan pemborosan, yaitu membeli barang-barang bermerk terkenal, yang notabene harganya jauh lebih mahal daripada barang-barang sejenis yang merk-nya kurang terkenal.

1. Tujuan kreatif

Kegiatan kampanye membutuhkan tujuan kreatif. Tujuan kreatif berfungsi sebagai tujuan dari pesan-pesan yang disampaikan, baik dalam bentuk verbal maupun visual. Tujuan kreatif kampanye kampanye pengurangan konsumtivisme dijabarkan sebagai berikut:

a. Membuat target audience sadar bahwa tindakannya membeli barang ber-merk selama ini adalah pemborosan.

b. Menciptakan konflik antara pembenci barang branded dan pecinta barang branded.

c. Menjadikan target audience sebagai media promosi kampanye ini dengan ikut menyebarkan pesan ini.

2. Strategi kreatif

Strategi kreatif adalah siasat, taktik, maupun langkah-langkah yang akan direncanakan dengan konsep kreatif dalam mencapai tujuan promosi. Strategi yang dibuat diharapkan dapat membuat khalayak tertarik, tergerak, dan terinspirasi untuk menjalankan pesan komunikasi kampanye ini. Strategi kreatif berkaitan erat dengan unique selling preposition (USP), yaitu keunggulan, keistimewaan, dan keunikan obyek yang dapat menjadi nilai jual. Strategi Kreatif yang digunakan dalam perancangan ini adalah menciptakan sebuah pemberitaan fiktif yang menceritakan betapa bodohnya orang yang membeli barang tidak sesuai dengan fungsinya.

a. Isi pesan

Isi pesan atau yang biasa disebut "what to say" merupakan hal yang penting dalam pembentukan komunikasi kampanye. Karena isi pesan merupakan pokok-pokok 
pemikiran yang akan membentuk dasar-dasar dan pendukung tema yang akan dibawa. Hal tersebut menjadi benang merah antara media-media yang digunakan.

Sehubungan dengan perancangan kampanye penggalangan dana ini, isi pesan yang akan dibawakan adalah: "Belilah barang sesuai dengan fungsinya". Konsumtivisme adalah perilaku berkonsumsi yang boros dan berlebihan yang lebih mendahulukan keinginan dari pada kebutuhan, serta tidak ada skala prioritas. Kita hidup di masyarakat modern yang mementingkan diri sendiri, kita sudah akrab dengan slogan - slogan atau motto - motto yg merangsang optimisme pribadi untuk mencapai apa yang kita inginkan; Standarstandar yang ditetapkan oleh masyarakat sosial untuk apa yang dinamakan "kemapanan" menjadi alasan masyarakat pada umumnya ingin meraih, mengeksploitasi sumber daya untuk terus naik masuk dalam komunitas kelas atas. Teriakan-teriakan zaman lewat multimedia, rangsangan-rangsangan yang membius oleh pengiklan yang ingin memasarkan produk sudah sering kita dengar.

b. Bentuk pesan

Bentuk pesan atau dapat disebut how to say, merupakan perkembangan dari isi pesan. Isi pesan yang telah terbentuk disesuaikan dengan psikologis target audience sehingga pesan yang disampaikan lebih relevan dan menarik bagi target audience. Hal tersebut dapat berupa komunikasi verbal maupun visual.

Kampanye ini menggunakan bentuk poster yang akan disebarkan di media sosial dengan karakter visual dan verbal yang kontroversial, diharapkan materi kontroversial tersebut dapat membantu target audience untuk turut menyebarkan pesan tersebut.

\section{Visualisasi}

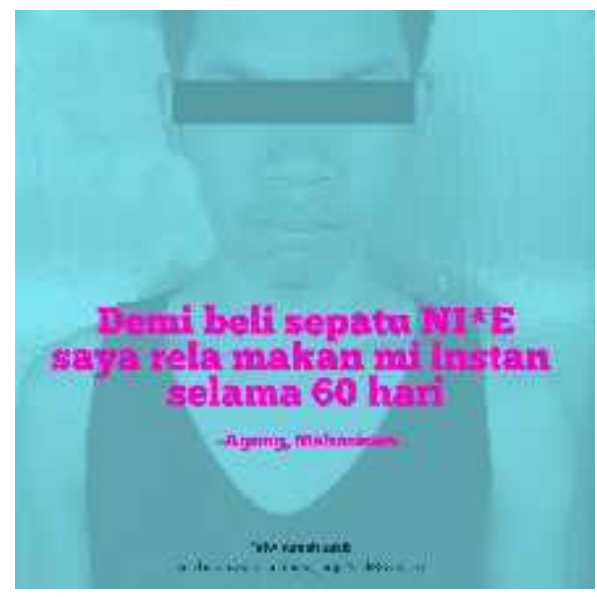

Gambar 14. Final desain poster 1 (Sumber: Elfa Swaratama)

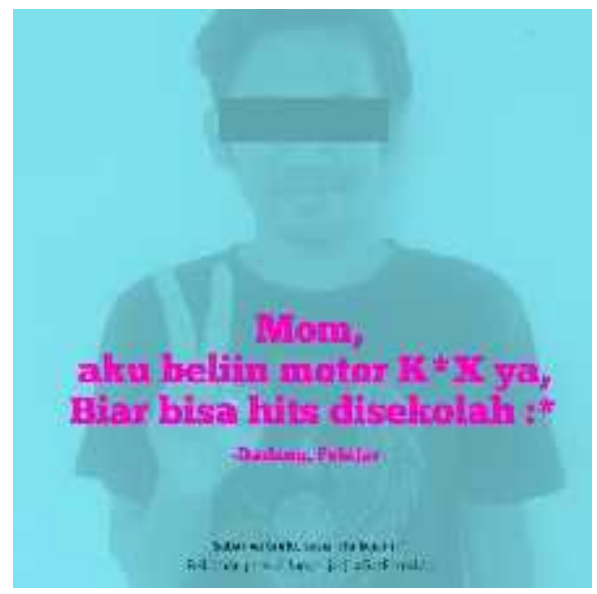

Gambar 15. Final desain poster 2 (Sumber: Elfa Swaratama) 


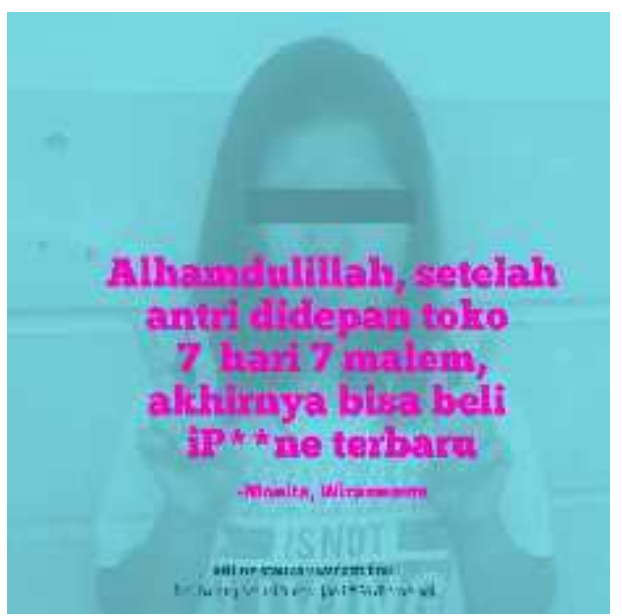

Gambar 16. Final desain poster 3 (Sumber: Elfa Swaratama)

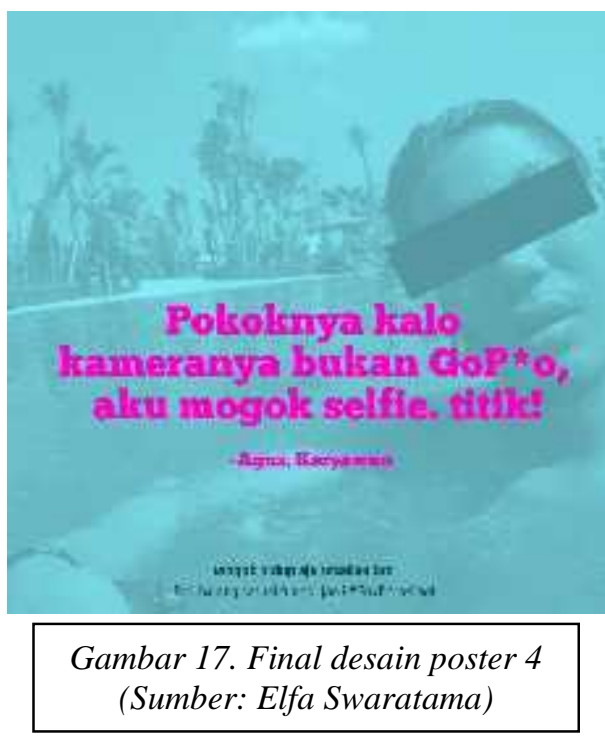

(Sumber: Elfa Swaratama)

\section{Kesimpulan}

Perilaku konsumtif dapat mengakibatkan berbagai dampak negatif seperti membuat seseorang untuk memiliki pola hidup boros dan dapat membuat sulit untuk membedakan antara kebutuhan dan keinginan. Perancangan Komunikasi Visual Kampanye Pengurangan Konsumtivisme ini bertujuan untuk mengurangi sifat konsumtif khususnya generasi muda. Metode pengumpulan data yang digunakan dalam perancangan ini adalah kualitatif deskriptif, serta perancangan ini melalui 3 tahap, yaitu pembuatan konsep kampanye, konsep media, dan pembuatan konsep kreatif berdasarkan studi literatur, observasi dan wawancara terhadap target audiens.

Berdasarkan penelitian berupa observasi dan wawancara terhadap target audiens didapati bahwa media-media yang akan digunakan sebagai media kampanye berdasarkan intensitas pemakaiannya ialah sosial media Facebook dan Instagram. Sedangkan isi pesan yang akan disampaikan adalah "Belilah barang sesuai dengan fungsinya", dengan cara penyajian pesan yaitu dengan menggunakan humor satir. Kampanye ini dirancang dalam bentuk 5 buah poster yang akan disebarkan di media sosial seperti yang telah disebutkan diatas, dengan karakter visual dan verbal yang kontroversial, diharapkan karakter tersebut dapat membantu target audiens untuk turut menyebarkan pesan tersebut sehingga kampanye ini akan menjadi viral.

Proses visualisasi dikerjakan dengan cara pengambilan foto, yang nantinya akan digunakan sebagai latar belakang poster yang berfungsi untuk mengilustrasikan pelaku yang mengucapkan kata-kata tersebut. Mata orang yang ada didalam foto ini akan ditutupi oleh bidang berwarna hitam. Untuk menyimbolkan bahwa orang-orang tersebut melakukan tindakan yang salah. Langkah selanjutnya ialah dengan melakukan studi 
warna. Warna yang digunakan dalam perancangan ini adalah warna-warna yang mencolok, karena berusaha untuk menarik perhatian target audience yang sedang browsing di media sosial. Setelah itu dilakukan studi layout dan tipografi untuk menentukan tipografi dan layout seperti apakah yang memiliki daya tarik dan readilibilitas yang tinggi sehingga bisa dengan cepat mendapatkan atensi audiens dan pesan yang disampaikan dengan tepat sasaran.

\section{Kepustakaan}

\section{Buku}

Antar, Venus. 2004. Manajemen Kampanye; Panduan Teoritis dan Praktis dalam Mengefektifkan Kampanye Komunikasi. Bandung: Simbiosa Rekaatam Media. Damsar. 2000. Sosiologi Ekonomi, Jakata: Raja Grafindo Persada.

Dietrich, Gini dan Livingston, Geoff. 2012. Marketing in the round: how to develop an integrated marketing campaign in the digital era. Indianapolis: Que Publishing.

Edell JA dan Burke MC. 1987. The power of feelings in understanding advertising effects. Journal of Consumer Research.

Kasali, Rhenald. 1992. Manajemen Periklanan. Bandung: PAU-Ekonomi-UI.

Liliweri, Alo. 1992. Dasar-dasar Komunikasi Periklanan. Bandung: Citra Aditya Bakti.

Lina, dkk. 2008. Perilaku Konsumtif Berdasar Locus of Control Pada Remaja Putri, Jakarta: Grafindo.

Schultz, Don E dan Barnez, Beth E. 1999. Strategic Brand Communication Campaigns Fifth Edition. NTC Contemporary: Illinois.

Sumardjo, Jakob. 2000. Filsafat Seni. Bandung: Penerbit ITB.

Sanyoto, Sadjiman Ebdi, 2006. Metode Perancangan Komunikasi Visual Periklanan.

Yogyakarta: Dimensi Press.

Tinarbuko, Sumbo. 2010. Semiotika Komunikasi Visual. Yogyakarta: Jalasutra.

Qualman, Eric. 2009. Socialnomics. New Jersey:WILEY John \& Sos, Inc.

\section{Disertasi}

Gupta, Kapil. 2011. Disertasi dari Master of Business Administration di University of Edinburgh Business School. Viral Marketing of Digital Product using Social Media. Disertasi tidak diterbitkan. Edinburgh

\section{E-Book}

Godin, Seth. 2000. Unleashing the Ideavirus. Do You Zoom, Inc.

\section{Pertautan:}

http://ciitha6.blogspot.com/2012/10/bab-i-pendahuluan-belakang-manusia.html diakses tanggal 21/11/2013 20:32

http://repository.stisitelkom.ac.id/145/1/Mohamad_Fauzi_112130175.pdf diakses tanggal 22/11/2013 16:30 
http://www.slideshare.net/sms2011/can-you-change-multinationals-strategies-with-socialmedia diakses tanggal 4/12/2013 12:55

http://fertobhades.wordpress.com/2007/11/29/satir-yang-menyindir/ diakses tanggal 6/1/2014 20:24

http://www.microsoft.com/en-us/news/stories/design/ diakses tanggal 23/01/2014 14:45 http://www.sysomos.com/reports/video/ diakses tanggal 11/03/2014 11:57

http://www.kompasiana.com/mulyady1688/10-peringkat-indonesiadidunia 54f934b0a333112c048b4a1a diakses tanggal 11/03/2014 11:00

\section{Informan:}

Alouisius Andito Deliza (25 tahun). Jabatan: Motion Creative, instansi: Rajawali Citra Televisi. 